\title{
RISK FACTORS OF TUBERCULOSIS: A NEW PATH ANALYSIS EVIDENCE FROM PONOROGO, EAST JAVA
}

\author{
Diana Sayidah'), Setyo Sri Rahardjo²), Bhisma Murti') \\ ${ }^{1)}$ Masters Program in Public Health, Universitas Sebelas Maret \\ ${ }^{2)}$ Faculty of Medicine, Universitas Sebelas Maret
}

\begin{abstract}
Background: Tuberculosis remains a major health problem worldwide. In 2016, 6.3 million new cases of TB were reported (up from 6.1 million in 2015), equivalent to $61 \%$ of the estimated incidence of 10.4 million. This study aimed to determine risk factors of tuberculosis in Ponorogo, East Java, using a path analysis model.

Subjects and Method: This was a case control study conducted in Ponorogo, East Java, from April to May 2018. A sample of 200 study subjects was selected for this study by fixed disease sampling, consisting of 100 adults with tuberculosis and 100 adults without tuberculosis. The dependent variable was tuberculosis. The independent variables were age, gender, education, nutritional status, dwelling density, smoking, and alcohol drinking. Data on tuberculosis infection status were obtained from the medical record at District Health Office Ponorogo. The data were collected by questionnaire and analyzed by path analysis model on Stata 13 .

Results: The risk of tuberculosis increased with $\mathrm{BMI} \geq 25(\mathrm{~b}=2.50 ; 95 \% \mathrm{CI}=0.51$ to $4.50 ; \mathrm{p}=0.014)$, smoking $(\mathrm{b}=2.42 ; 95 \% \mathrm{CI}=0.74$ to $4.11 ; \mathrm{p}=0.005)$, lack of lighting $(\mathrm{b}=3.11 ; 95 \% \mathrm{CI}=1.34$ to $4.86 ; \mathrm{p}=0.001)$, alcohol drinking $(\mathrm{b}=2.15 ; 95 \% \mathrm{CI}=$ 0.75 to $3.56 ; \mathrm{p}=0.003)$, densed dwelling $(\mathrm{b}=2.31 ; 95 \% \mathrm{CI}=0.69$ to $3.92 ; \mathrm{p}=$ $0.005)$, and age $\geq 44$ years $(\mathrm{b}=1.51 ; 95 \% \mathrm{CI}=-0.01$ to $3.02 ; \mathrm{p}=0.051)$. The risk of tuberculosis was indirectly affected by education.
\end{abstract}

Conclusion: The risk of tuberculosis increases with BMI, smoking, lack of lighting, alcohol drinking, dwelling density, and age $\geq 44$ years.

Keywords: tuberculosis, age, dwelling density, smoking, alcohol drinking, education

\section{Correspondence:}

Diana Sayidah. Masters Program in Public Health, Universitas Sebelas Maret, Jl. Ir. Sutami No. 36 A, Surakarta 57126, Central Java.

Email: dianasayidah13@gmail.com. Mobile: +6282234721294

The 4th International Conference on Public Health

Best Western Premier Hotel, Solo, Indonesia, August 29-30, 2018 | 104 https://doi.org/10.26911/theicph.2018.01.65 